\title{
1. PRE-MESOZOIC BASEMENT OF THE WESTERN IBERIAN CONTINENTAL MARGIN AND ITS PLACE IN THE VARISCAN BELT ${ }^{1}$
}

\author{
Raymond Capdevila, Centre Armoricain d'Etude Structurale des Socles (CNRS), Université de Rennes I, Rennes, \\ France \\ and \\ Denis Mougenot, Groupe d'Etude de la Marge Continentale, Laboratoire de Géodynamique Sous-Marine du \\ CEROV, Villefranche-sur-Mer, France
}

\begin{abstract}
The study of plutonic and metamorphic rock samples from 15 dredge hauls and 41 cores from the western Iberian margin has led to the recognition of westward extension of the zones of the Iberian Massif Variscides. The offshore area studied appears to consist of several zones, from north to south:

Central Iberian Zone on the continental shelf of Galicia and northern Portugal

Ossa-Morena Zone from Galicia Bank to south of Nazaré Canyon

South Portuguese Zone to the south of Lisbon

These zones were located where the continents fit together prior to the opening of the Atlantic. This position limits tracing of the Ossa-Morena Zone north from the western margin of the Iberian Massif, because the zone abuts units of the Rheno-Hercynian Zone. Toward the west, the Ossa-Morena Zone is adjacent to Avalon Zone formations that were unaffected by the Hercynian Orogeny. It appears that the Ossa-Morena Zone corresponds to the eastern margin of the Avalon Zone, which was involved in the Hercynian Orogeny.

The proposed new structural arrangement of the Iberian-Armorican Arc contrasts with previous cylindrical geodynamic models and rejects the classic correlations between the South Portuguese and Rheno-Hercynian Zones and between the Ossa-Morena and Saxo-Thuringian Zones.
\end{abstract}

\section{INTRODUCTION}

Syntheses concerning the Hercynian fold belt present a wide range of possible correlations between the Iberian segment of this chain and the neighboring domains of Europe, North America, and Africa (Dewey and Burke, 1973; Riding, 1974; Ries and Shackleton, 1976; Lefort, 1983; Lorenz and Nicholls, 1984; Ziegler, 1986; Vaï and Cocozza, 1986). Part of the difficulty in establishing these correlations is due to the lack of detailed knowledge of the Hercynian basement of the western Iberian margin. Uncertainty about this region, which comprises one fifth of the Iberian Peninsula, has caused previous authors to note it as an area of uncertain tectonic affinity, and its attribution to fold belt zones has been of a highly speculative nature.

Nevertheless, some information is available on the nature of the Hercynian basement at the western Iberian margin. Study of the 15 dredge and 41 core samples collected across this area over the past 15 years gives evidence of the presence of continental basement. Sampling at the northern part of the margin (Fig. 1) includes cores from the inner shelf (Boillot et al., 1975) and dredges from the slopes of Galicia Bank and Vigo and Vasco da Gama seamounts (Dupeuble et al., 1976; Mauffret et al., 1978; Groupe Galice, 1979; Boillot et al., 1979; Mougenot et al., 1985). Dredge samples collected from the Nazaré Canyon and around the small islands of Berlengas and Farilhões (Boillot et al., 1975) in the central part of the margin complement previous information from these islands (Andrade, 1937). Additionally, numerous cores (and two dredge hauls on the continental slope) from areas farther south-between the Cape of Sines

\footnotetext{
${ }^{1}$ Boillot, G., Winterer, E. L., et al., 1988. Proc. ODP, Sci. Results, 103: College Station, TX (Ocean Drilling Program).
}

and Cape São Vicente (Fig. 2)-have also recovered Hercynian basement (Baldy et al., 1977).

The total sample set consists of about 100 samples of continental basement rock, representative of a relatively homogenous distribution across the western Iberian margin (Figs. 1 and 2). The samples appear to be consistent with a pattern of tectonic zonation, thus enabling a broad description of basement characteristics, which in turn leads to an extrapolation onto the margin of the zones observed in the Iberian Hercynides.

\section{TECTONIC ZONATION IN THE IBERIAN HERCYNIDES}

The Iberian Hercynides have been subdivided into several zones parallel to the Hercynian tectonic trend (Lotze, 1945) and analogous to those zones described previously in Central Europe (Fig. 3) by Kossmat (1927). Paleogeographic, volcanic, structural, metamorphic and plutonic aspects characterizing the zones are summarized in Table 1 . The zones are bounded either by deep-seated faults that were reactivated several times during the Paleozoic or by sutures, such as the Porto-Badajoz-Cordoba suture separating the Central Iberian Zone from the Ossa-Morena Zone (Burg et al., 1981) and the Theic Ocean suture separating the Ossa-Morena Zone from the South Portuguese Zone (Lefort, 1983). The diversity of the Central Iberian Zone has prompted its proposed division into two subzones, although there is no structural discontinuity across the subdivision.

The classic zoned representation of the Hercynian fold belt has been supplanted by a more explicit geodynamic picture (e.g., fig. 1 in Matte, 1986). Nevertheless, the zonation established by Lotze (1945) is still useful for describing the fold belt and providing criteria for correlation. Such correlation was the primary objective of this study, in attempting to link offshore 


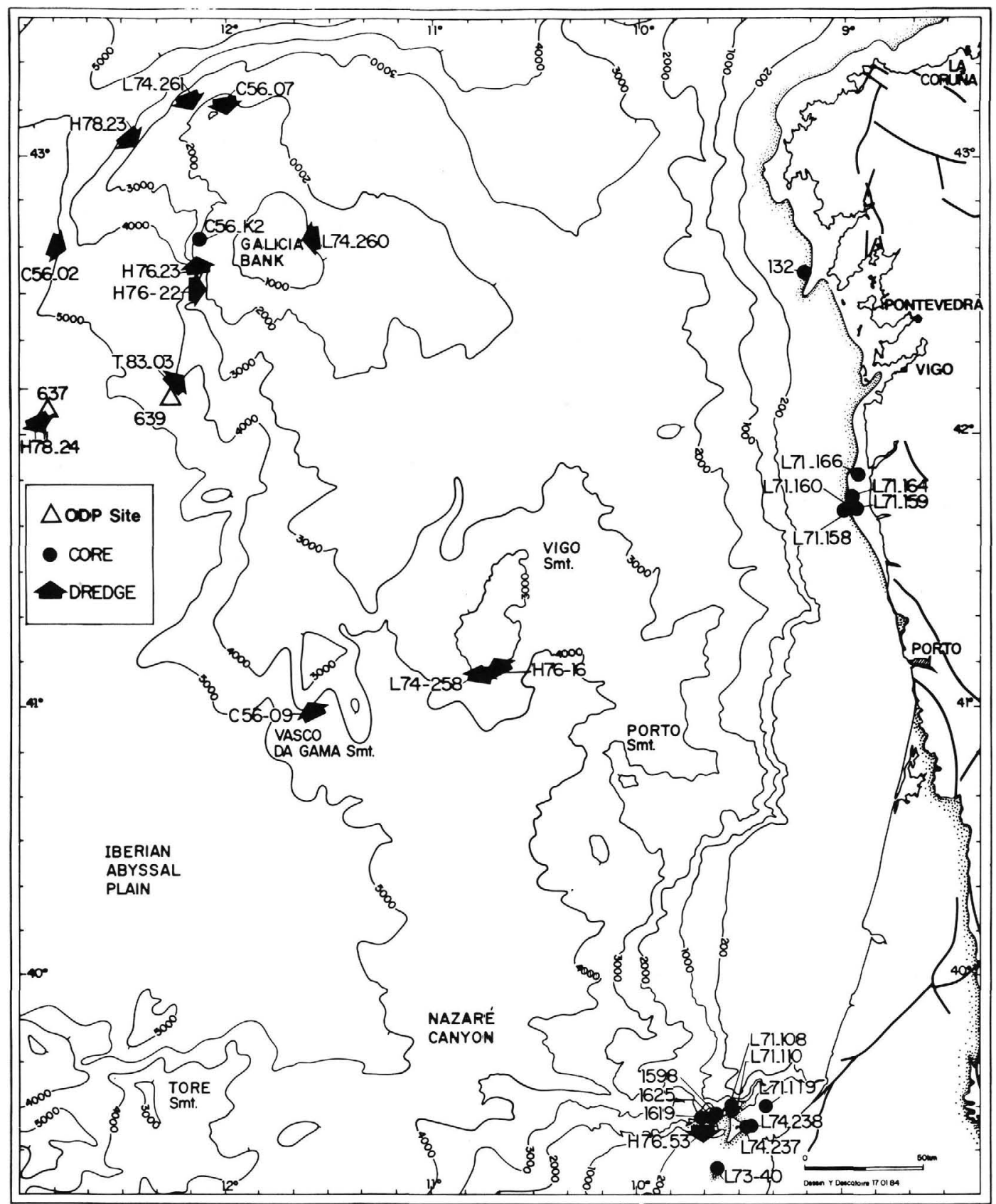

Figure 1. Simplified bathymetric map of the continental margin northwest of the Iberian Peninsula (after Laughton et al., 1975), showing positions of pre-Mesozoic basement samples. Stippled line indicates outcrop limit of post-Hercynian cover, including offshore areas. Bathymetric contours in meters.

basement areas on the western Iberian margin to basement outcrops in Spain and Portugal.

\section{NATURE OF THE WESTERN IBERIAN MARGIN BASEMENT}

\section{Basement off the Galicia Coast and Northern Portugal}

Several cores taken off the coast of northern Portugal recovered rock samples identical to nearby mainland outcrops (Fig. 1). Core 132 (from north of Pontevedra) sampled the Caldas de Reis granite. Cores L71-158 and L71-166 consist of greenschist facies feldspathic quartzites, micaschists, and metarhyolites corresponding to the Ordovician-Silurian formations of the synclinorium east of Porto, in the Central Iberian Zone.

\section{Basement of the Northwest Iberian Continental Slope}

Most of the data concerning the western Iberian margin comes from samples of the Galicia Bank, the westernmost segment of continental crust belonging to the Iberian Massif. Nine dredge hauls (Table 2), nearly all from areas west of the bank, were found to contain predominantly metamorphic rocks of sedimentary origin belonging to the low-pressure amphibolite facies and a variety of granitic rock types. The latter include abundant biotite or biotite-hornblende tonalites and peraluminous granites. In addition, there are minor amounts of lowgrade metasediments and low- to intermediate-pressure granulites.

The distribution of rock types appears to follow a pattern. The two dredges from the northwestern slope of Galicia Bank 


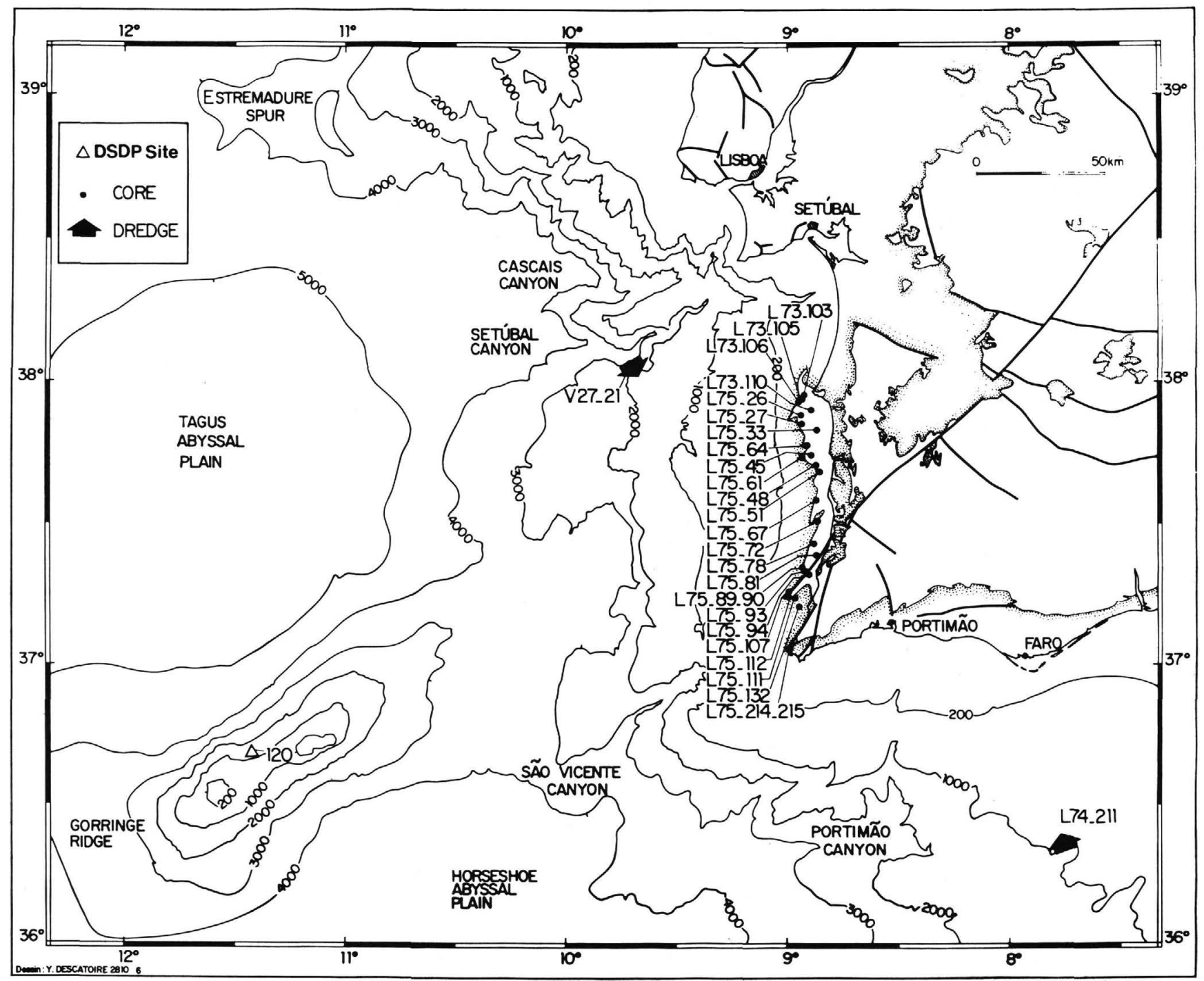

Figure 2. Simplified bathymetric map of the continental margin southwest of the Iberian Peninsula (after Laughton et al., 1975), showing positions of pre-Mesozoic basement samples. Stippled line indicates outcrop limit of post-Hercynian cover, including offshore areas. Bathymetric contours in meters.

(C56-07 and L74-261) both contain the same types of peraluminous granite and micaschist. Greenschist facies metasediments and cataclastic biotite-bearing granodiorites were recovered in three deep-water dredges (C56-09, T83-03, and H78-23) from between Vasco da Gama Seamount and Galicia Bank. Granulites were found in two dredge hauls (L74-258 and L74-260) from shallower water nearer the coast. This distribution suggests that the local zonation in the crust reflects the presence of progressively shallower tectono-metamorphic units toward the west.

The geological history of the basement can be reconstructed as follows. Initial deposits of mudstones, arkosic sandstones, and some calcareous sediments were metamorphosed and deformed with slaty cleavage or schistose foliation. Crenulation is visible in the least metamorphosed facies. According to relationships between deformation and mineral growth, greenschist or low-pressure amphibolite metamorphism continued after the main phase of deformation. A late-stage crenulation is synchronous with retrogression. Plutonic activity that accompanied and followed these tectono-metamorphic events included the early intrusion of calc-alkaline granitic rocks and peraluminous leu- cogranites (now deformed), followed by peraluminous granites or calc-alkaline granites, granodiorites, and tonalites (undeformed). The granulites (1500 m.y. old; Postaire, 1983) form part of a pre-Hercynian basement complex.

To summarize, the nature and development of the continental slope basement northwest of the Iberian Peninsula are similar to those known from the internal zones of the mainland Hercynian fold belt, as observed in western Galicia and the Ossa-Morena Zone (Julivert et al., 1977, 1980). However, the dredge granulites have no onshore equivalents; the granulites from the northwestern Iberian nappes are of the high-pressure type and are probably Paleozoic in age (J. J. Peucat, pers. comm., 1986).

\section{Basement to the West of Nazaré Canyon}

Hercynian basement crops out to the south of Nazaré Canyon around the islets of Berlengas and Farilhões (Table 2). This group of small islands consists of biotite-bearing monzonitic granites (Berlengas) and deformed muscovite-bearing or twomica leucogranites and pelitic gneisses (Farilhões) (Andrade, 1937; Andrade and Brack-Lamy, 1949). Sampling around the is- 
Table 1. Summary of Iberian basement characteristics.

\begin{tabular}{|c|c|c|c|}
\hline \multicolumn{2}{|c|}{ ZONES } & SEDIMENTATION & PALEOZOIC VOLCANISM \\
\hline \multicolumn{2}{|c|}{ 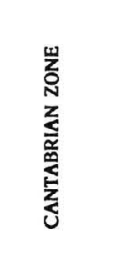 } & $\begin{array}{l}\text { I - Upper Proterozoîc : thick turbidite-bearing succession, } \\
\text { slightly deformed before deposition of the Cambrian. } \\
2 \text { - Cambrian-Visean : thin succession of platform deposits } \\
\text { with sedimentary breaks; correspond to shallow-water } \\
\text { sedimentation. } \\
3 \text { - Namurian-Westphalian : thick sequences made up mostly } \\
\text { of turbidites. } \\
\text { 4- Westphalian D - Stephanian : post tectonic molasse. }\end{array}$ & $\begin{array}{l}\text { Minor phases of activity during the } \\
\text { Mid-Cambrian and Caradoc : basic and } \\
\text { intermediate volcanism of alkaline } \\
\text { affinity. }\end{array}$ \\
\hline \multicolumn{2}{|c|}{ 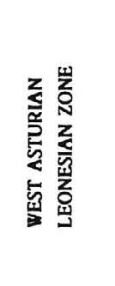 } & $\begin{array}{l}\text { 1- Upper Proterozoic : thick turbidite- bearing succession, } \\
\text { slightly deformed before deposition of the Cambrian. } \\
2 \text { - Cambrian-Lower Devonian : very thick succession of } \\
\text { shallow-water deposits, followed by Caradoc turbidites, } \\
\text { thinnly developed Silurian black shales (transgressive) and } \\
\text { Lower Devonian reef facies. } \\
3 \text { - Lower Carboniferous : scarce outcrops of } \\
\text { turbidite-bearing facies. } \\
4 \text { - Westphalian-Stephanian : post-tectonic molasse. }\end{array}$ & $\begin{array}{l}\text { Minor basaltic and rhyolitic activity } \\
\text { during the Caradoc. }\end{array}$ \\
\hline \multirow{2}{*}{ 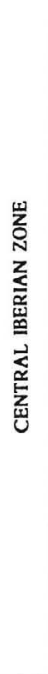 } & 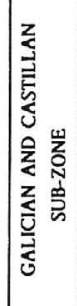 & $\begin{array}{l}\text { I - Upper Proterozoic : Peraluminous, acid volcanics at the } \\
\text { northern boundary of the sub-zone. Elsewhere, a thick } \\
\text { turbidite-bearing succession. Slight deformation before the } \\
\text { deposition of Palaeozoic strata. } \\
2 \text { - Pre-Hercynian Palacozoic formations : No significant } \\
\text { outcrop of dated Cambrian. Discordant Ordovician } \\
\text { succession of moderate thickness formed of quartzites at } \\
\text { the base passing up into mudstones. Thick sequence of } \\
\text { Silurian turbidites in the North of the sub-zonc. Rare } \\
\text { outcrops of turbidite-bearing Lower Carboniferous. }\end{array}$ & $\begin{array}{l}\text { Major acid volcanism of alkaline } \\
\text { affinity, with occasional basic } \\
\text { volcanism, during the Silurian. }\end{array}$ \\
\hline & 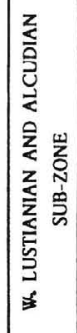 & $\begin{array}{l}\text { 1 - Upper Proterozoic : Thick turbidite-bearing succession, } \\
\text { slightly deformed before depositions of ? Vendian strata. } \\
2 \text { - Vendian-Cambrian : A thin, incomplete succession of } \\
\text { shallow-water deposits slightly deformed before deposition } \\
\text { of the Ordovician. } \\
3 \text { - Ordovician-Upper Devonian : A mainly sandy and shaly } \\
\text { succession of moderate thickness corresponding to shallow } \\
\text { water facies. } \\
4 \text { - Lower Carboniferous : Culm facies. } \\
\text { S- Westphalian : limnic facics. } \\
\text { Stephanian : molasse deposits. }\end{array}$ & $\begin{array}{l}\text { Minor acid and basic volcanism during } \\
\text { the Ordovician. Silurian spilites. } \\
\text { Basic volcanism during the Late } \\
\text { Devonian. }\end{array}$ \\
\hline \multicolumn{2}{|c|}{ 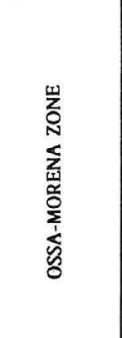 } & $\begin{array}{l}\text { I - Proterozoic: Polyphase metamorphic complex and thick } \\
\text { turbidite-bearing succession, both strongly affected by } \\
\text { Cadomian orogenesis. } \\
2 \text { - A thick Cambrian succession represented by platform } \\
\text { facies at the base, followed by a turbidite-bearing sequence } \\
\text { containing basic volcanics. Sandy-shaly facies in the } \\
\text { ordovician coresponding to deep-water deposits. The Silurian } \\
\text { contains volcanics and black shales. Lower-Mid Devonian } \\
\text { shows platform facies. } \\
3 \text { - Upper Devonian : turbidite-bearing facies. } \\
4 \text { - Stephanian : limnic facies. }\end{array}$ & $\begin{array}{l}\text { Major spilitic volcanism during the } \\
\text { Mid-Cambrian. Oceanic tholeiites of } \\
\text { ordovician age. } \\
\text { Major acid and basic volcanism during } \\
\text { the Silurian. }\end{array}$ \\
\hline & 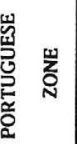 & $\begin{array}{l}\text { Upper Devonian : sandstones and shales. } \\
\text { Lower Carboniferous : volcano-sedimentary complex. } \\
\text { Upper Visean-Namurian : turbidites. }\end{array}$ & $\begin{array}{l}\text { Major volcanic phase with spilites and } \\
\text { quartz-keratophyres during the } \\
\text { Tournaisian-Visean. }\end{array}$ \\
\hline
\end{tabular}

lets (Boillot et al., 1975) and on the southern flank of Nazaré Canyon (Andrade, 1937) has yielded undeformed porphyritic granites containing biotite and hornblende (H76-53), deformed muscovite-bearing or two-mica leucogranites (L71-108), and various pelitic or semipelitic schists with sericite, chlorite, biotite, and albitized plagioclase (dredge L73-40; cores 1598, 1619, 1625, L74-237, and L74-238). A variety of schists with large porphyroblasts of chlorite and rutile that occurs as reworked material within a conglomerate (L71-119) is identical to rock types from the Vasco da Gama Seamount. Therefore, it is apparent 


\begin{tabular}{|c|c|c|}
\hline $\begin{array}{l}\text { PRINCIPAL PHASES OF } \\
\text { HERCYNIAN DEFORMATION (D) }\end{array}$ & HERCYNIAN REGIONAL METAMORPHISM & HERCYNIAN PLUTONISM \\
\hline $\begin{array}{l}\text { D1 - Westphalian : overthrusts and nappes of décollement } \\
\text { with assymetric folds facing towards the interior of the } \\
\text { cantabrian arc. } \\
\text { D2 - Upper Westphalian - Stephanian : Flexure folds. }\end{array}$ & $\begin{array}{l}\text { Incipient metamorphism localized in the S.E. part of the } \\
\text { zone. }\end{array}$ & $\begin{array}{l}\text { Small scarce granitic (sensu lato) stocks of the } \\
\text { calc-alkaline, post-tectonic type. }\end{array}$ \\
\hline $\begin{array}{l}\text { Dr - Lower Carboniferous : fold nappes in the West of the } \\
\text { zone passing into overturned folds which face the interior } \\
\text { of the regional fold-arc in the East, associated with a } \\
\text { foliation or a flow schistosity. } \\
\text { D2 - ? Namurian : folding and thrusting, with formation of } \\
\text { strain slip cleavage. } \\
\text { D }_{3} \text { - Westphalian : upright folds crenulation cleavage. }\end{array}$ & $\begin{array}{l}\text { Most of the zone is metamorphosed in the greenschist } \\
\text { facies, apart from the N.W. which is in the amphibolite } \\
\text { facies. Metamorphism is intermediate between the medium } \\
\text { pressure and the low pressure types: the peack is attained } \\
\text { between deformation phases Di and D2 or during } D_{2} \text {. }\end{array}$ & $\begin{array}{l}\text { Small scarce granitic (sensu lato) massifs of the } \\
\text { calk-alkaline or peraluminous, post-tectonic type, mostly of } \\
\text { Upper Carboniferous age, throughout the zone, except in } \\
\text { the NW where medium-sized massifs are observed as } \\
\text { follows: } \\
\text { - Lower Carboniferous : syntectonic peraluminous } \\
\text { leucogranites. } \\
\text { - Upper Carboniferous : post-tectonic cal-alkaline granites } \\
\text { and granodiorites. }\end{array}$ \\
\hline 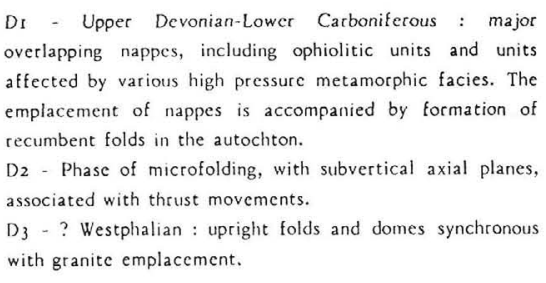 & $\begin{array}{l}\text { Plurifacial metamorphism in the autochtone, generally with } \\
\text { in the amphibolite facies, begining with a metamorphism } \\
\text { intermediate between the medium pressure and the low } \\
\text { pressure types and terminating with low pressure type } \\
\text { during the } D_{3} \text { phase. }\end{array}$ & $\begin{array}{l}\text { Large batholiths and medium-sized massifs as follows: } \\
\text { - Lower-Mid Carboniferous : synorogenic calc-alkaline } \\
\text { granodiorites and peraluminous leucogranitcs. } \\
\text { - Upper Carboniferous : late stage orogenic granodiorites, } \\
\text { calc-alkaline granites and peraluminous leucogranites. }\end{array}$ \\
\hline Dr - Lower Carboniferous : upright folds. & Most of this sub-zone is in the greenschist facies. & $\begin{array}{l}\text { Large batholiths and medium-sized massifs as follows : } \\
\text { - Lower Carboniferous : scarce synorogenic peraluminous } \\
\text { leucogranites. } \\
\text { - Upper Carboniferous : numerous late-stage massifs of } \\
\text { biotite granite, two-mica granite and biotite-cordierite } \\
\text { granite. }\end{array}$ \\
\hline $\begin{array}{l}\text { D1 - Upper Devonian : overlapping nappes and recumbent } \\
\text { folds facing SW, associated with formation of cleavage. } \\
\text { D2 - Pre-Stephanian : upright folds or overfolded to the } \\
\text { SW, accompanied by crenulation cleavage. }\end{array}$ & $\begin{array}{l}\text { Most of the zone is in the greenschist facies. Low pressure } \\
\text { amphibolite facies is locally developped and becomes more } \\
\text { and more important towards the N.E. }\end{array}$ & $\begin{array}{l}\text { Small to medium-sized massifs : } \\
\text { - Lower-Mid Carboniferous : syn-orogenic gabbros, diorites, } \\
\text { tonalites, granodiorites, calc-alkaline granites and some } \\
\text { rare peraluminous leucogranites (in the NE of the zone). } \\
\text { - Stephanian : late-stage and post-orogenic gabbros, } \\
\text { diorites, tonalites, granodiorites and cale-alkaline granites. }\end{array}$ \\
\hline $\begin{array}{l}\text { D1 - Westphalian : overlapping nappes and overfolds facing } \\
\text { SW, accompanied by formation of cleavage. } \\
\text { D2 - Post-Westphalian : upright folds with local } \\
\text { development of crenulation cleavage. }\end{array}$ & $\begin{array}{l}\text { Metamorphism decreases gradually from NE to SW, showing } \\
\text { a zonation from the chlorite zone, through the } \\
\text { prehnite-pumpellyite facies to very low grade. }\end{array}$ & $\begin{array}{l}\text { Race post-tectonic massifs of gabbro, diorite and granite } \\
\text { localized in the NE of the zone. }\end{array}$ \\
\hline
\end{tabular}

that the basement of the Portuguese continental shelf to the south of Nazaré Canyon is similar to that observed on the continental slope northwest of the Iberian Peninsula.

\section{Continental Margin Basement to the Southwest of the Iberian Peninsula}

Pre-Mesozoic basement also crops out on the inner shelf of the South Portuguese margin between the Cape of Sines and the
Cape São Vicente (Fig. 2). Coring here yielded rocks belonging to the South Portuguese Zone (Baldy et al., 1977). For the most part, samples are made up of clastic sedimentary rocks assigned as follows:

1. A flysch (Culm facies) formation of late Visean-Westphalian age (graywackes, coarse- or fine-grained mudstones, small-scale and sand-shale sequences; L75-26, L75-33, L75-45, 
L75-48, L75-51, L75-64, L75-67, L75-72, L75-81, L75-90, L7593, L75-94, L75-132, L75-214, L75-215, L73-103, L73-106, and L73-110).

2. A "Sub-Culm" volcano-sedimentary formation of Tournaisian-early Visean age (tuffs and mudstones; L75-61, L75-78, L75-89, L75-111, and L75-112).

3. Quartzitic phyllites and orthoquartzites of late Devonian age (L73-105 and L75-27). A silicified dolomitic limestone of probable early Carboniferous age (L75-107) was sampled also. These facies are typical of the South Portuguese Zone; their offshore occurrences are a result of Tertiary faulting (Mougenot et al., 1979). Similarly emplaced Culm flysch facies have been recovered in dredges from the continental slope to the south of the Setubal Canyon (V27-21; Fig. 2) and on the Guadalquivir Bank south of the Algarve (L74-211; Table 2).

\section{CORRELATION OF THE WESTERN IBERIAN MARGIN BASEMENT AND THE IBERIAN MESETA}

Samples from the Galicia and northern Portuguese continental shelf belong to the Central Iberian Zone, whereas samples from the southwestern Iberian margin between the Cape of Sines and Cape São Vicente are part of the South Portuguese Zone. The basement of the northwestern Iberian continental slope (Galicia Bank and Vasco da Gama and Vigo seamounts) has a consistent assemblage of rock types that correlate with mainland Hercynian zonations on the basis of metamorphic and plutonic criteria. The tonalites and biotite-hornblende granodiorites commonly found in the Ossa-Morena Zone are well represented on the northwestern Iberian continental slope. In contrast, the abundant peraluminous leucogranites of Galicia (Central Iberian Zone) are rarely found on the slope. The typical features of overlapping nappes in the Central Iberian Zone of Galicia and northwestern Portugal are absent from the margin; these features include amphibolites of meta-igneous origin, eclogites, high-pressure granulites, garnet peridotites, and peralkaline orthogneisses.

Based on this evidence, we propose that the basement of the northwestern Iberian margin correlates with the Ossa-Morena Zone. The Berlengas-Farilhões archipelago and the continental shelf basement south of the Nazaré Canyon, which has strong affinities with offshore areas to the north and with mainland outcrops to the south, provide evidence for continuity between the northwestern Iberian margin and the Ossa-Morena Zone. The petrographic observations from offshore samples (Table 2) are in good agreement with interpretations given by Lefort et al. (1981) and Lefort (1983), who propose that the Porto-BadajozCordoba suture extends toward the north, parallel with the shelf break off Galicia, which suggests that a contact between the Ossa-Morena and South Portuguese Zones should be found near Lisbon.

\section{DISCUSSION}

\section{Extension of the Ossa-Morena Zone}

According to cylindrical geotectonic models, the Ossa-Morena Zone continues north through France into Central Europe, where it is equivalent to the Central German Crystalline Rise (Ellenberger and Tamain, 1980) or the Saxo-Thuringian Zone (Julivert and Martinez, 1983). Another model traces the OssaMorena Zone westward into Africa and North America (Vai and Cocozza, 1986). It is possible to test these models by comparing the nature prior to the opening of the Atlantic of the basement massifs adjacent to the northwestern Iberian margin (Fig. 3).
Table 2. Dredge samples from the West Iberian margin.

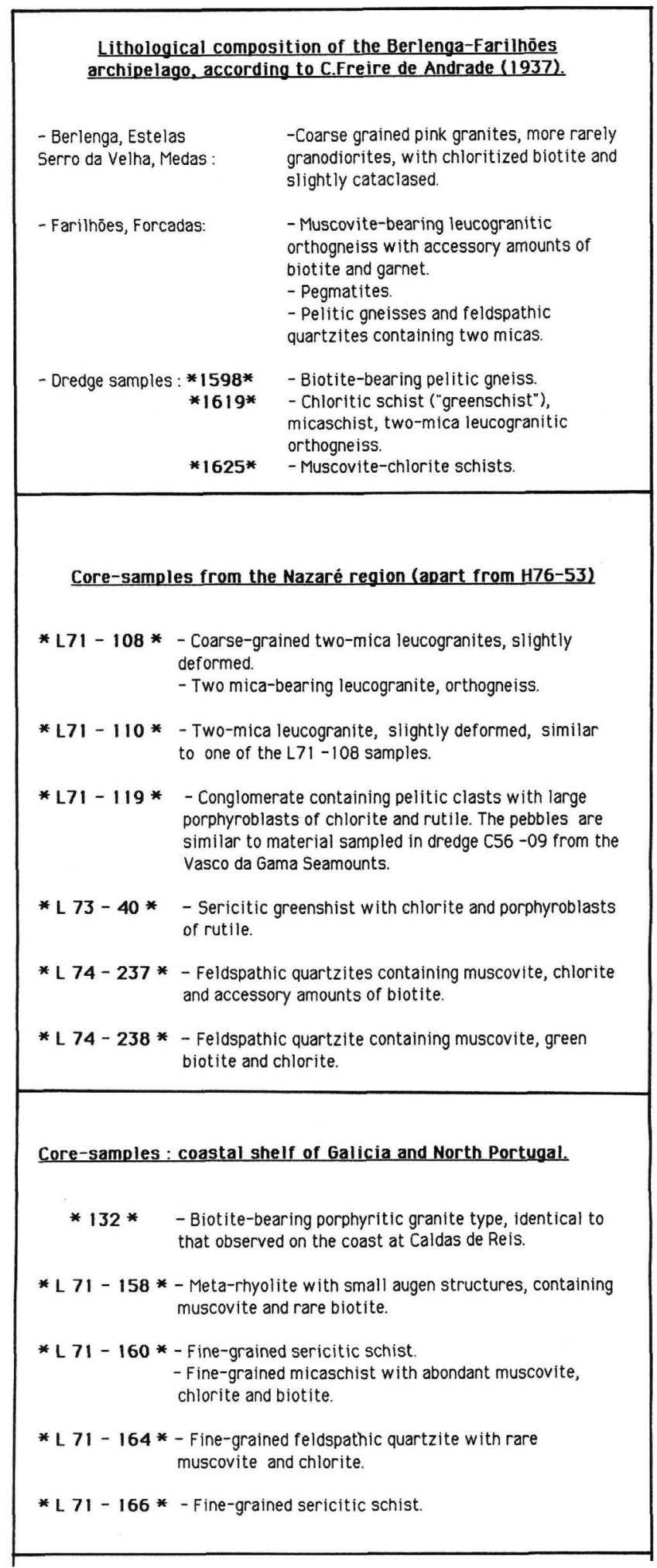

Models showing the fit of the continents before the opening of the North Atlantic generally place Galicia Bank just south of Flemish Cap in such a way that the northwestern scarp of Galicia Bank is in continuity with the southeastern scarp of Flemish Cap (Olivet et al., 1984; Lefort, 1985). The Flemish Cap base- 
Table 2 (continued).

\begin{tabular}{|c|c|c|c|}
\hline SAMPLES LOCATION & LITHOLOGY & SAMPLES LOCATION & LITHOLOGY \\
\hline $\begin{array}{l}\text { *H } 78-23 * \\
\text { - Univ. Paris VI - } \\
\text { NW Slope of Galicia Bank } \\
43^{\circ} 04^{*} \mathrm{~N}-12^{\circ} 27 \mathrm{~W} \\
3900-3200 \mathrm{~m} \text { water depth }\end{array}$ & $\begin{array}{l}\text { - Strongly cataciased biotite-bearing } \\
\text { granodiorite, with development of chlorite } \\
\text { and epidote at the expense of primary } \\
\text { biotite and plagioclase. }\end{array}$ & \multirow[t]{2}{*}{$\begin{array}{l}* \text { T83 - 03* } \\
\text { - Univ. Paris VI - } \\
\text { W Slope of Galicia Bank } \\
42^{\circ} 1 I^{\prime} \mathrm{N}-12^{\circ} 14^{\prime} \mathrm{W} \\
4700-4000 \text { m water depth }\end{array}$} & \multirow{2}{*}{$\begin{array}{l}\text { - Slightly deformed muscovite-biotite } \\
\text { leucogranite. } \\
\text { - Cataclased biotite-bearing granodiorite, } \\
\text { similar to that of H78- } 23 \text {. } \\
\text { - Fine-grained sericite schist with } \\
\text { chlorite and green biotite, -similar to } \\
\text { Ordovician mainland outcrops. } \\
\text { - Sericitic phyllite with chlorite and } \\
\text { organic matter, similar to Silurian } \\
\text { mainland outcrops. } \\
\text { - Red sandstones with carbonate cement, } \\
\text { illite-rich, feldspar-poor with mica and } \\
\text { kaolinite. Similar to Stephanian-Autunian } \\
\text { formations on land of the Buçaco type. } \\
\text { - Undeformed greywackes and lithic } \\
\text { sandstones with abundant clay-rich matrix. } \\
\text { Similar to Permo-Carboniferous outcrops } \\
\text { on land. }\end{array}$} \\
\hline $\begin{array}{l}* \mathrm{~L} 74-261 * \\
\text { - Univ. Paris VI- } \\
\text { NW Slope of the Galicia Bank } \\
43^{\circ} 12^{\circ} \mathrm{N}-12^{\circ} 10^{\prime} \mathrm{W} \\
3000-2600 \text { m water depth }\end{array}$ & $\begin{array}{l}\text { - Porphyritic, monzonitic granites with } \\
\text { biotite and muscovite, slightly cataclased } \\
\text { and chloritized. One sample contains garnet } \\
\text { and sillimanite. } \\
\text { - Undeformed, chloritized microtonalite } \\
\text { rich in biotite. } \\
\text { - Fine-grained micaschists with abundant } \\
\text { biotite and rare muscovite in the matrix. } \\
\text { Small porphyroblasts of biotite and } \\
\text { muscovite cut across the foliation. Green } \\
\text { tourmaline. }\end{array}$ & & \\
\hline \multirow[t]{2}{*}{$\begin{array}{l}\text { * C } 56-07 * \\
\text { - CNEXO- } \\
\text { NW Slope of the Galicia Bank } \\
43^{\circ} 10^{\prime} \mathrm{N}-12^{\circ} 00^{\prime} \mathrm{W} \\
1900-1800 \mathrm{~m} \text { water depth }\end{array}$} & \multirow{2}{*}{$\begin{array}{l}\text { - Two-mica, porphyritic granites identical } \\
\text { to those in } L 74-261 \text {. } \\
\text { - Fine grained micaschists with abundant } \\
\text { biotite. Large porphyroblasts of biotite and } \\
\text { muscovite identical to those in } L 74-261 \text {. } \\
\text { Green tourmaline. } \\
\text { - Banded gneiss. Psammitic layers contain } \\
\text { plagioclase, green amphibole and } \\
\text { sometimes biotite. Calc-silicate layers } \\
\text { rich in garnet, diopside and zoisite. Rare } \\
\text { sphene, carbonate and scapolite are } \\
\text { crystallized in cracks oblique to the } \\
\text { foliation. }\end{array}$} & $\begin{array}{l}* \text { L74 - } 260 * \\
\text { - Univ. Paris VI- } \\
\text { E Border of the Galicia Bank } \\
42^{\circ} 42^{\prime} \mathrm{N}-11^{\circ} 35^{\prime} \mathrm{W} \\
1400-1000 \mathrm{~m} \text { water depth }\end{array}$ & $\begin{array}{l}\text { - Undeformed, coarse-grained monzoritic } \\
\text { granite with biotite. } \\
\text { - Light coloured, undeformed tonalite with } \\
\text { biotite chloritized. Comparable with } \\
\text { tonalites from L } \mathrm{L} 74-26 \mathrm{\text {and }} \mathrm{H} 76-23 \text {. } \\
\text { - Pebbles of granulites: hornblende- } \\
\text { bearing pyriclasites with variable amounts } \\
\text { of amphibole; enderbitic gneiss. }\end{array}$ \\
\hline & & \multirow{2}{*}{$\begin{array}{l}* \text { C56 - } 09 * \\
- \text { C NEX } 0- \\
\text { Vasco da Gama Seamounts } \\
40^{\circ} 58^{\circ} \mathrm{N}-11^{\circ} 33^{\prime} \text { W } \\
4100-3800 \mathrm{~m} \text { water depth }\end{array}$} & \multirow{2}{*}{$\begin{array}{l}\text { - Phyllites very similar to those of T83 - } \\
\text { 03. Large porpnyroblasts of chlorite and } \\
\text { biotite (later chloritized) in a matrix of } \\
\text { quartz and sericite. Large porphyroblastic } \\
\text { rutile prisms. } \\
\text { - Meta-arkoses interbedded within the } \\
\text { phyllites: coarse grained layers with } \\
\text { detrital quartz and plagioclase surrounded } \\
\text { by a fine sericitic cement. Porphyroblasts } \\
\text { of chlorite, chloritized biotite and rutile. } \\
\text { Green tourmaline. }\end{array}$} \\
\hline $\begin{array}{l}\text { * C } 56-02 * \\
\text { - C NEX X - } \\
\text { External ridge of Galicia Bank } \\
42^{\circ} 39^{\prime} \mathrm{N}-12^{\circ} 50^{\circ} \mathrm{W} \\
4800-4500 \mathrm{~m} \text { water depth }\end{array}$ & $\begin{array}{l}\text { - Serpentinite with characteristic "mesh" } \\
\text { structure; chrysotile and antigorite. } \\
\text { Altered olivine. }\end{array}$ & & \\
\hline $\begin{array}{l}\text { * H } 78-24 * \\
\text { - Univ. Paris VI - } \\
\text { External ridge of Galicia Bank } \\
42^{\circ} 02^{\prime} \mathrm{N}-12^{\circ} 5 I^{\prime} \mathrm{W} \\
5200-5000 \mathrm{~m} \text { water depth }\end{array}$ & $\begin{array}{l}\text { - Highly altered Iherzolite. Primary } \\
\text { orthopyroxene, clinopyroxene and spinel } \\
\text { oriented parallel to early foliation. } \\
\text { Secondary serpent Ine mineral (lizardite) } \\
\text { replacing olivine, enstatite and diopside. } \\
\text { - Breccia with clay-rich cement and } \\
\text { angular clasts of extremely altered } \\
\text { peridotite identical to serpentinites at } \\
\text { this locality. }\end{array}$ & $\begin{array}{l}\text { * L74 - } 258^{*} \\
\text { - Univ. Paris VI - } \\
\text { Vigo Seamount } \\
41^{\circ} 08^{\prime} \mathrm{N}-10^{\circ} 45^{\prime} \mathrm{W} \\
3400-2800 \mathrm{~m} \text { water depth }\end{array}$ & $\begin{array}{l}\text { - Tonalitic orthogneiss with biotite and } \\
\text { hornblende. } \\
\text { - Granodioritic orthogneiss with biotite. } \\
\text { - Granulites: khondalitic/kinzigitic } \\
\text { gneisses; acid charnockite; hornblende- } \\
\text { garnet pyriclasite; ultrabasic orthopy- } \\
\text { roxene- bearing granulite with amphibole, } \\
\text { olivine and phlogopite. }\end{array}$ \\
\hline \multirow[t]{3}{*}{$\begin{array}{l}\text { * H } 76-23 * \\
\text { - Univ. Paris VI- } \\
\text { W Slope of Galicia Bank } \\
42^{\circ} 36^{\prime} \mathrm{N}-12^{\circ} 07 \mathrm{~W} \\
3000-2500 \mathrm{~m} \text { water depth }\end{array}$} & \multirow{3}{*}{$\begin{array}{l}\text { - Medium grained, undeformed tonalites } \\
\text { with biotite and hornblende. } \\
\text { - Coarse grained tonalite with biotite, } \\
\text { highly chloritized, similar to micro- } \\
\text { tonalite of } L 74-261 \text {. } \\
\text { - Fine-grained quartzo-feldspathic gneiss } \\
\text { of sedimentary origin containing oligocla- } \\
\text { se, biotite and variable amounts of } \\
\text { microcline. } \\
\text { - Banded gneisses very similar to those of } \\
\text { dredge C } 56-07 \text {. Calc-silicate layers } \\
\text { contain diopside, colourless clinoamphi- } \\
\text { boles and zoisite. Microcline is present } \\
\text { in certain bands. Cracks cutting across } \\
\text { foliation are sealed with scapolite. }\end{array}$} & $\begin{array}{l}\text { * H76 - } 16 * \\
\text { - Univ. Paris VI - } \\
\text { Vigo Seamount } \\
41^{\circ} 09^{\prime} \mathrm{N}-10^{\circ} 41^{\prime} \mathrm{W} \\
3100-2600 \mathrm{~m} \text { water depth }\end{array}$ & $\begin{array}{l}\text { - Deformed biotite-bearing granite. } \\
\text { - Hornblende pyriclasites with accessory } \\
\text { amounts of biotite. }\end{array}$ \\
\hline & & $\begin{array}{l}\text { * H76 - } 53 * \\
\text { - Univ. Paris VI - } \\
\text { Nazaré Canyon } \\
39^{\circ} 24^{\prime} \mathrm{N}-9^{\circ} 38^{\prime} \mathrm{W} \\
1000-600 \mathrm{~m} \text { water depth }\end{array}$ & $\begin{array}{l}\text { - Light-coloured, undeformed biotite- } \\
\text { bearing granodiorites with accessory } \\
\text { amounts of hornblende. Relatively rich in } \\
\text { sphene, apatite and zircon. }\end{array}$ \\
\hline & & \multirow{2}{*}{$\begin{array}{l}\text { * v27 - 21* } \\
\text { - Lamont D.G.O. - } \\
\text { 5etúbal Canyon } \\
38^{\circ} 02^{\prime} \mathrm{N}-9^{\circ} 42^{\prime} \mathrm{W} \\
2700-2200 \mathrm{~m} \text { water depth }\end{array}$} & \multirow{2}{*}{$\begin{array}{l}\text { - Greywacke-mudstones (Culm facies) } \\
\text { with graded, laminated units parallel } \\
\text { to So bedding stratification. Quartz, } \\
\text { chlorite and some muscovite and } \\
\text { tourmaline. Slight } S 1 \text { schistosity parallel } \\
\text { to So. Phyllites are microfolded about } \\
\text { axes oblique to So which def ine S2 } \\
\text { schistosity. }\end{array}$} \\
\hline \multirow[t]{3}{*}{$\begin{array}{l}\text { * H } 76-22 * \\
\text { - Univ. Paris VI - } \\
\text { W Slope of Galicia Bank } \\
42^{\circ} 3 I^{\prime} \mathrm{N}-12^{\circ} 07^{\prime} \mathrm{W} \\
3900-2800 \mathrm{~m} \text { water depth }\end{array}$} & \multirow{2}{*}{$\begin{array}{l}\text { - Cataclased potassic granophyre with rare } \\
\text { biotite and muscovite. } \\
\text { - Micaschits with large porphyroblasts of } \\
\text { biotite, muscovite, cordierite and pink } \\
\text { andalusite. Apart from the two last } \\
\text { minerals, these samples are similar to } \\
\text { micaschists of L74-261 and C56-07. }\end{array}$} & & \\
\hline & & \multirow{2}{*}{$\begin{array}{l}\text { * L74 - } 211 * \\
\text { - Univ. Paris VI - } \\
\text { Guadalquivir Bank } \\
36^{\circ} 21^{\prime} \mathrm{N}-7^{\circ} 45^{\prime} \mathrm{W} \\
1100-800 \mathrm{~m} \text { water depth }\end{array}$} & \multirow{2}{*}{$\begin{array}{l}\text { - Culm facies greywacke. Angular, detrital } \\
\text { quartz with some mica and tourmaline. } \\
\text { Quartzo-sericitic cement with chlorite, } \\
\text { limonite and micritic calcite. }\end{array}$} \\
\hline & & & \\
\hline
\end{tabular}




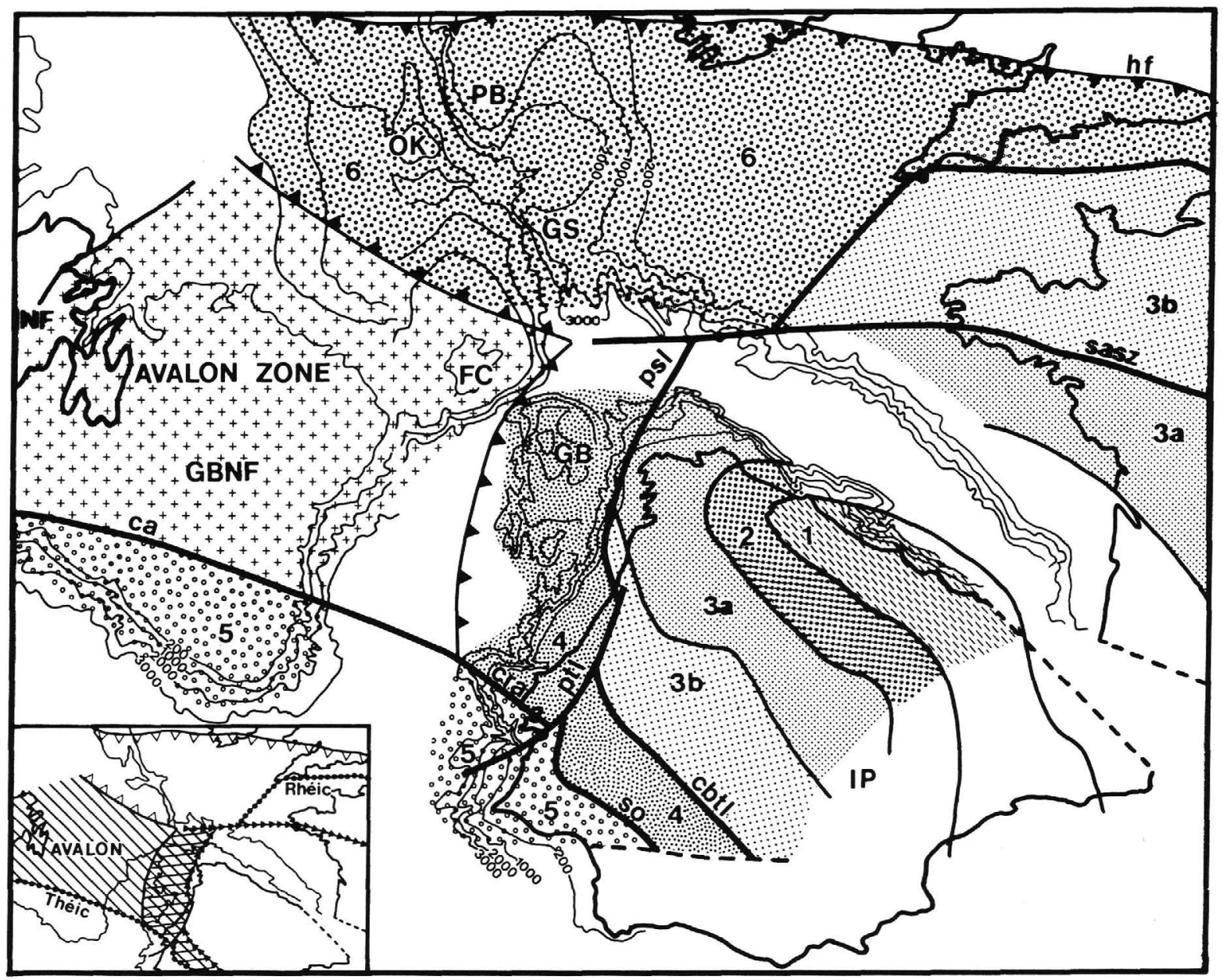

Figure 3. Tectono-metamorphic zonation of the Hercynian fold belt in Iberia and adjoining regions. Positions of the continents prior to the opening of the Atlantic modified from Lefort (1983). 1 = Cantabrian Zone; 2 = West Asturian and Leonesian Zone; $3 \mathrm{a}=$ Galician and Castillan Subzone (Iberia) and South Armorican Zone (France); $3 \mathrm{~b}=$ West Lusitanian and Alcudian Subzone (Iberia) and North and Central Armorican Zone (France); $3 a+3 b=$ Central Iberian Zone (Iberia); 4 = Ossa-Morena Zone; $5=$ South Portuguese Zone; 6 = Rheno-Hercynian Zone; hf = Hercynian Front; sasz = South Armorican Shear Zone; psl = Petite Sole lineament; cbtl = Cordoba-Badajoz-Tomar lineament; ptl = Porto-Tomar lineament; psl + cbtl + ptl = Porto-BadajozCordoba suture; $\mathrm{cra}=$ Cap de la Roca anomaly; $\mathrm{ca}=$ "Collector" anomaly, equivalent to Theic Ocean suture; so = Ficalho overthrust; IP = Iberian Peninsula; GB = Galicia Bank; GBNF = Grand Banks of Newfoundland; NF = Newfoundland; FC = Flemish Cap; OK = Orphan Knoll; PB = Porcupine Bank; GS = Goban Spur. In France, zones 3a and 3b are separated by a suture (e.g., see Matte, 1986), whereas on the Iberian Peninsula the boundary between the equivalent domains is gradual. These data are consistent with the opening of a South Armorican Ocean during the Early Paleozoic, as suggested by Lefort and Ribeiro (1980), and constrain the width of this small ocean. Insert shows the distribution of the Hercynian fronts (triangles), Rheic and Theic oceans sutures (dots), South Armorican and Porto-Badajoz-Cordoba sutures (arrows), Avalon Zone (lines), and OssaMorena Zone segment of the Avalon Zone that was reactivated during the Hercynian Orogeny (crossed lines).

ment is composed of granodiorites emplaced between 833 and $751 \mathrm{Ma}$ ago, as well as Hadrynian acidic volcanics of low-metamorphic grade that have been unaffected by orogenesis since the end of pan-African events (King et al., 1985). The basement of the central part of the Grand Banks includes unmetamorphosed or poorly metamorphosed Paleozoic strata in addition to Precambrian formations (Lilly, 1965; Jansa and Wade, 1975); in particular, the Devonian contains organic-walled microplankton that have not experienced any metamorphism (Jenkins, 1974). The basement of the Canadian margin appears to have been little affected by the Acadian Orogeny and was not involved in the Hercynian; therefore, this type of basement cannot be linked directly to the western Iberian margin, where there are abundant Hercynian granitic and metamorphic rocks.

By the same line of reasoning, Devonian and Carboniferous sediments from the Goban Spur (Auffret et al., 1979; Lefort et al., 1985) are too poorly deformed and metamorphosed to belong to the internal zones of the Hercynian fold belt.

Thus, it is not possible to extend the northwestern Iberian margin basement either to the north or to the west, as proposed in previous models. As a consequence, the Ossa-Morena Zone is delimited by the northern and western flanks of the Galicia Bank. The boundary of the Ossa-Morena Zone to the north of Galicia Bank corresponds to the South Armorican Shear Zone (Fig. 3), and to the west, the Ossa-Morena Zone is apparently bounded by another suture or a Hercynian front.

\section{Extension of the South Portuguese Zone}

Cylindrical models of fold belts connect the Rheno-Hercynian Zone with the South Portuguese Zone (Oliveira et al., 1979; Franke and Engel, 1986). Some of these models suggest extension of the South Portuguese Zone into North Africa (Dewey 
and Burke, 1973; Lorenz and Nicholls, 1984). Other models separate the South Portuguese Zone and Rheno-Hercynian Zone by a metamorphic belt (Vaï and Cocozza, 1986) or by a domain that was undeformed during the Hercynian, including eastern Newfoundland, the Grand Banks, and Flemish Cap (Lefort, 1983).

Given that no samples that could have belonged to the South Portuguese Zone are observed on the northwestern Iberian margin and that there appears to be no room for extension of the South Portuguese Zone between the northwestern Iberian margin and the central part of the Grand Banks, it would seem that the hypothesis of joining the Rheno-Hercynian Zone and South Portuguese Zone should be abandoned. Rather, it is more likely that the South Portuguese Zone belongs to the northern African margin and is bounded to the north by the Theic Ocean suture (Fig. 3), which is marked by a strong magnetic anomaly to the south of the Grand Banks (the "Collector" anomaly; Lefort, 1983).

\section{Significance of the Ossa-Morena Zone and Western Boundary of the Iberian-Armorican Arc}

The Precambrian and pre-Carboniferous Paleozoic formations of the Ossa-Morena Zone display African affinities and are fundamentally different from other formations of the same age in the Iberian Peninsula (Herranz Araujo, 1984; Robardet, 1982). Paleomagnetic measurements from the Ossa-Morena Zone also evidence the separation of this zone from Iberia prior to the Late Paleozoic (Perroud et al., 1985). These two lines of argument indicate that the Ossa-Morena Zone and the rest of Iberia belonged to different tectonic plates before the Devonian, with the suture zone represented by the Porto-Badajoz-Cordoba lineament (Burg et al., 1981).

Preceding the opening of the Atlantic, the fit of the continents positioned the Avalon Zone (eastern Newfoundland, central and northern Grand Banks, and Flemish Cap), which was not affected by the Hercynian Orogeny (Haworth and Lefort, 1979), opposite the offshore extension of the Ossa-Morena Zone on the western Iberian margin. Either a suture, which could be an extension of the Rheic Ocean suture (Matte, 1986), or an Hercynian front must exist between these two domains. No trace of a suture has been found between Flemish Cap and the Galicia margin; the peridotites recovered on Ocean Drilling Program Leg 103 were emplaced during the Mesozoic and cannot be interpreted as Paleozoic ophiolitic slices (Boillot et al., 1980, 1985, 1986; Girardeau et al., this volume).

The Proterozoic history of the Ossa-Morena Zone is similar to that of the Avalon Zone (Herranz Araujo, 1984), the latter of which is considered as part of a pan-African belt added to North America during the Paleozoic (O'Brien et al., 1983). Therefore, the Ossa-Morena Zone probably corresponds to that part of the Avalon Zone that was deformed and metamorphosed with the Iberian Peninsula during the Hercynian plate collision. The contact between the east Canadian and west Iberian continental margins should broadly correspond to one of the fronts of the Hercynian fold belt and would also be the western structural boundary of the Iberian-Armorican Arc.

\section{CONCLUSIONS}

The pre-Mesozoic basement of the western Iberian continental margin consists of formations belonging to the Central Iberian, Ossa-Morena, and South Portuguese Zones of the mainland Iberian Hercynian fold belt.

The Ossa-Morena Zone forms the major part of the western Iberian margin and appears to be bounded by several sutures and major faults: the Porto-Badajoz-Cordoba lineament to the east, a probable Theic Ocean suture to the south, a Hercynian front to the west, and a possible extension of the South Armorican Shear Zone to the north.

The eastern border of the Avalon Zone could have been involved in the Hercynian Orogeny, with the Ossa-Morena Zone interpreted as belonging to this type of basement. Under these conditions, the external zones of the Hercynides (i.e., the RhenoHercynian and South Portuguese Zones) are not directly linked to but continue as parallel belts to the north and south of the Avalon Zone (Fig. 3). Thus, study of the western Iberian margin basement leads to the proposition of a new structural pattern for the Iberian-Armorican Arc that is more complex and less dependant on large-scale cylindrical arrangements than previous models.

\section{ACKNOWLEDGMENTS}

This study was undertaken with the encouragement of G. Boillot, who supplied material from the various sampling campaigns under his direction. During the preparation of this paper we benefited from discussions with J. P. Lefort. Samples from the South Portuguese Zone were studied by D. Fantinet. W.B.F. Ryan kindly supplied the samples from dredge V27-D27, and IFREMER supplied material from dredges C56-07/09. M.S.N. Carpenter was responsible for translation of the French text. We thank all co-workers and colleagues for their fruitful collaboration and M. Julivert, P. Matte, and A. W. Meyer for their comments and suggestions.

Contribution no. 428 of the "Groupe d'Etude de la Marge Continentale" (U.A. 718, CNRS).

\section{REFERENCES}

Andrade, F. C., 1937. Os vales submarinos portugueses e o diastrofismo das Berlengas e da Estramadura. Mem. Serv. Geol. Port., 1.

Andrade, F. C., and Brack-Lamy, J., 1949. Afloramentos eruptivos do ilhiéu da Berlenga. Bol. Mus. Lab. Mineral. Geol., Fac. Cienc. Univ. Lisboa, 5(17):3-9.

Auffret, G. A., Pastouret, L., Cassat, G., de Charpal, O., Cravatte, J., and Guennoc, P., 1979. Dredged rocks from the Armorican and Celtic margins. In Montadert, L., Roberts, D. G., et al., Init. Repts. DSDP, 48: Washington (U.S. Govt. Printing Office), 955-1014.

Baldy, P., Boillot, G., Dupeuble, P. A., Malod, J., Moita, I., and Mougenot, D., 1977. Carte géologique du plateau continental sudportugais et sud-espagnol (Golfe de Cadix). Bull. Soc. Geol. Fr., 19: 703-724.

Boillot, G., Auxiètre, J. L., Dunand, J. P., Dupeuble, P. A., and Mauffret, A., 1979. The northwestern Iberian margin: a Cretaceous passive margin deformed during Eocene. In Talwani, M., Hay, W., and Ryan, W.B.F. (Eds.), Deep Drilling Results in the Atlantic Ocean: Continental Margin and Paleoenvironment: Am. Geophys. Union, Maurice Ewing Ser., 3:138-153.

Boillot, G., Dupeuble, P. A., and Musellec, P., 1975. Carte géologique du plateau continental nord-portugais. Bull. Soc. Geol. Fr., 17:422480.

Boillot, G., Grimaud, S., Mauffret, A., Mougenot, D., Kornprobst, J., Mergoil-Daniel, J., and Torrent, G., 1980. Ocean-continent boundary off the Iberian margin: a serpentinite diapir west of the Galicia Bank. Earth Planet. Sci. Lett., 48:23-34.

Boillot, G., Recq, M., Winterer, E. L., Meyer, A. W., Applegate, J., Baltuck, M., Bergen, J. A., Comas, M. C., Davies, T. A., Dunham, K., Evans, C. A., Girardeau, J., Goldberg, D. G., Haggerty, J., Jansa, L. F., Johnson, J. A., Kasahara, J., Loreau, J.-P., Luna-Sierra, E., Moullade, M., Ogg, J., Sarti, M., Thurow, J., and Williamson, M. A., 1986. Amincissement de la croûte continentale et dénudation tectonique du manteau supérieur sous les marges stables: a la recherche d'un modèle. L'exemple de la marge occidentale de la Galice (Espagne). Bull. Cent. Rech. Explor. Prod. Elf Aquitaine, 10: 95-104.

Boillot, G., Winterer, E. L., Meyer, A. W., Applegate, J., Baltuck, M., Bergen, J. A., Comas, M. C., Davies, T. A., Dunham, K., Evans, C. A., Girardeau, J., Goldberg, D. G., Haggerty, J., Jansa, L. F., Johnson, J. A., Kasahara, J., Loreau, J.-P., Luna-Sierra, E., Moullade, M., Ogg, J., Sarti, M., Thurow, J., and Williamson, M. A., 1985. Résultats préliminaires de la campagne 103 du Joides Resolution (ODP) au large de la Galice (Espagne): sédimentation et disten- 
sion pendant le rifting d'une marge stable; hypothèse d'une dénudation tectonique du manteau supérieur. C. R. Acad. Sci. Ser. 2, 301: $627-632$.

Burg, J. P., Iglesias, P., Laurent, P., Matte, P., and Ribeiro, A., 1981. Variscan intracontinental deformation: the Coimbra-Cordoba shear zone (SW Iberian Peninsula). Tectonophysics, 78:161-177.

Dewey, J. F., and Burke, K.C.A., 1973. Tibetan, Variscan and Precambrian basement reactivation: products of continental collision. $J$. Geol., 81:683-692.

Dupeuble, P. A., Rehault, J. P., Auxiètre, J. L., Dunand, J. P., and Pastouret, L., 1976. Résultats de dragages et éssai de stratigraphie des bancs de Galice et des montagnes de Porto et de Vigo (marge occidentale ibérique). Mar. Geol., 22:M37-M49.

Ellenberger, F., and Tamain, A.L.G., 1980. Hercynian Europe. Episodes, 1:22-27.

Franke, W., and Engel, W., 1986. Synorogenic sedimentation in the Variscan Belt of Europe. Bull. Soc. Geol. Fr., 2:25-33.

Groupe Galice, 1979. The continental margin off Galicia and Portugal: acoustical stratigraphy, dredge stratigraphy and structural evolution. In Sibuet, J.-C., Ryan, W.B.F., et al., Init. Repts. DSDP, 47, Pt. 2: Washington (U.S. Govt. Printing Office), 633-662.

Haworth, R. T., and Lefort, J. P., 1979. Geophysical evidence for the extent of the Avalon Zone in Atlantic Canada. Can. J. Earth Sci., 16:552-567.

Herranz Araujo, P., 1984. El Precambrico del NE de "Ossa-Morena": planteamiento y estado de la cuestion, unidades, bases para su correlation y esquema evolutivo. Cuad. Geol. Iber., 9:119-211.

Jansa, L. F., and Wade, J. A., 1975. Geology of the continental margin off Nova Scotia and Newfoundland. In Offshore Geology of Eastern Canada: Pap. Geol. Surv. Can., 64-30(2):51-105.

Jenkins, W.A.M., 1974. Age determinations in the interval 10,000 to 10,949 feet (T.D.) of Amoco A-1 Murre G-67 well, Grand Banks, Newfoundland. Intern. Rep. Geol. Surv. Can., EPGS-PAL., WAMJ., 8-74.

Julivert, M., Fontbote, J. M., Ribeiro, A., and Nabais Conde, L. E., 1977. Memoria explicativa del Mapa Tectonico de la Peninsula Iberica y Baleares. Mapa Geol. Esp.

Julivert, M., and Martinez, F. J., 1983. Estructura de conjunto y vision global de la cordillera hercyniana. In Rios, J. M. (Ed.), Geologia de Espana: Mem. Gen., Inst. Geol. Min. Esp., 1:612-630.

Julivert, M., Martinez, F. J., and Ribeiro, A., 1980. The Iberian segment of the European Hercynian foldbelt. Mem. BRGM, 108:132158.

King, L. H., Fader, G. B., Poole, W.-H., and Wanless, R. K., 1985. Geological setting and age of the Flemish Cap granodiorite, east of the Grand Banks of Newfoundland. Can. J. Earth Sci., 22:12861298.

Kossmat, F., 1927. Gliederung des Varistischen Gebirgsbaues. Abh. Saech. Akad. Wiss. Leipzig, Math. Naturwiss, 1:1-39.

Laughton, A. S., Roberts, D. G., and Graves, R., 1975. Bathymetry of the northeast Atlantic: Mid-Atlantic Ridge to southwest Europe. Deep Sea Res., Part A, 22:791-810.

Lefort, J. P., 1983. A new geological criterion to correlate the Acadian and Hercynian orogenies of western Europe and eastern America. Mem. Geol. Soc. Am., 158:3-18.

1985. The main basement features recognized in the northern part of the North Atlantic area. In de Graciansky, P. C., Poag, C. W., et al., Init. Repts. DSDP, 80: Washington (U.S. Govt. Printing Office), 1103-1114.

Lefort, J. P., Alveirinho-Dias, J., Monteiro, J. H., and Ribeiro, A., 1981. L'organisation des structures profondes du socle à l'Ouest de la Faille Porto-Tomar-Bajadoz: apport des données géophysiques. Comun. Serv. Geol. Port., 67:57-63.
Lefort, J. P., Peucat, J. J., Deunff, J., and Le Herissé, A., 1985. The Goban Spur Paleozoic basement. In de Graciansky, P. C., Poag, C. W., et al., Init. Repts. DSDP, 80: Washington (U.S. Govt. Printing Office), 677-679.

Lefort, J. P., and Ribeiro, A., 1980. La faille Porto-Badajoz-Cordoue at-elle controlé l'évolution de l'océan paléozoîque sud-armoricain? Bull. Soc. Geol. Fr., 22:455-462.

Lilly, H. D., 1965. Submarine examination of the Virgin Rocks area, Grand Banks, Newfoundland: preliminary note. Geol. Soc. Am. Bull., 76:131-132.

Lorenz, V., and Nicholls, I. A., 1984. Plate and intraplate processes of Hercynian Europe during the Late Paleozoic. Tectonophysics, 107: 25-56.

Lotze, F., 1945. Zur gliederung der varisziden der Iberischen Meseta. Geotekton. Forsch., 6:78-92.

Matte, P., 1986. Tectonics and plate tectonics model for the Variscan belt of Europe. Tectonophysics, 126:329-374.

Mauffret, A., Boillot, G., Auxiètre, J. L., and Dunand, J. P., 1978. Evolution structurale de la marge continentale au nord-ouest de la Péninsule Ibérique. Bull. Soc. Geol. Fr., 20:375-388.

Mougenot, D., Capdevila, R., Palain, C., Dupeuble, P. A., and Mauffret, A., 1985. Nouvelles données sur les sédiments anté-rift et le socle de la marge continentale de Galice. C. R. Acad. Sci. Ser. 2, 301: 323-328.

Mougenot, D., Monteiro, J. H., Dupeuble, P. A., and Malod, J. A., 1979. La marge continentale sud-portugaise: évolution structurale et sédimentaire. Cienc. Terra, 5:223-246.

O'Brien, S. J., Wardle, R. J., and King, A. F., 1983. The Avalon Zone: a pan-African terrane in the Appalachian Orogen of Canada. J. Geol., 18:195-222.

Oliveira, J. T., Horn, M., and Paproth, E., 1979. Preliminary note on the stratigraphy of the Baixo Alentejo Flysch Group, Carboniferous of southern Portugal and on the palaeogeographic development, compared to corresponding units in northwest Germany. Comun. Serv. Geol. Port., 65:151-168.

Olivet, J. L., Bonnin, J., Beuzart, P., and Auzende, J. M., 1984. Cinématique de l'Atlantique Nord et Central. Publ. Cent. Natl. Exploit. Oceans, Rapp. Sci. Tech. (Fr.), 54.

Perroud, H., Bonhommet, N., and Ribeiro, A., 1985. Paleomagnetism of Late Paleozoic igneous rocks from southern Portugal. Geophys. Res. Lett., 12:45-48.

Postaire, B., 1983. Systématique $\mathrm{Pb}$ commun et U-Pb sur zircons. Applications aux roches de haut grade métamorphique impliquées dans la chaine hercynienne (Europe de l'Ouest) et aux granulites de Laponie (Finlande). Bull. Soc. Geol. Mineral. Bretagne, C15:29-72.

Ries, A. C., and Shackleton, R. M., 1976. Patterns of strain variation in arcuate fold belts. Philos. Trans. R. Soc. London, A, 283:281288.

Riding, R., 1974. Model of the Hercynian fold belt. Earth Planet. Sci. Lett., 24:125-135.

Robardet, M., 1982. The Silurian-earliest Devonian succession in south Spain (Ossa Morena Zone) and its paleogeographical signification. IGCP Newsl., 4:72-77.

Vaï, G. B., and Cocozza, T., 1986. Tentative schematic zonation of the Hercynian chain in Italy. Bull. Soc. Geol. Fr., 28:95-114.

Ziegler, P. A., 1986. Geodynamic model for the Palaeozoic crustal consolidation of Western and Central Europe. Tectonophysics, 126:303328.

Date of initial receipt: 5 January 1987

Date of acceptance: 10 August 1987

Ms 103B-116 